\title{
The Portrayal of Jews in Seventeenth- and Eighteenth-Century Monastery Chronicles from the Polish-Lithuanian Commonwealth on the Basis of Selected Examples*
}

\begin{abstract}
Monastery chronicles from the Polish-Lithuanian Commonwealth provide valuable insight not only into the history of individual orders and the Polish clergy in general, but also into the history of mentality, daily life and religious and ethnic minorities. Although references to Jews are rather sporadic in such chronicles, they are nevertheless quite diverse and concern almost all aspects of Jewish activity in Poland and abroad. Therefore, they can serve as an excellent complement to other sources in the field, including Jewish ones, and those of various secular institutions and offices. It should be noted, however, that the credibility of the information contained in monastery chronicles is always dependent on the distance in time and space between the chronicler and the described events and should - if possible — be verified against other documentary sources from the same period.
\end{abstract}

Keywords: monastery chronicles, converts, host desecration, ritual murders, tenants.

" Polish edition: Stefan Gąsiorowski, "Obraz Żydów w siedemnasto- i osiemnastowiecznych kronikach klasztornych z terenów Rzeczypospolitej na wybranych przykładach," Studia Judaica 19 (2016), 2: 251-273.

The special edition of the journal Studia Judaica, containing the English translation of the best papers published in 2016, was financed from the sources of the Ministry of Science and Higher Education for promotion of scientific research, according to the agreement 508/P-DUN/2016. 
To begin with, it should be noted that records have been kept in monasteries on Polish lands from very early on, first as annals in the margins of calendars, and later in expanded forms such as chronicles and diaries. Their content is various and has expanded over time to include new sections and subject matter. In addition to content concerning establishment and remuneration, the chronicles also include lists of monastery superiors, benefactors, deceased monks and nuns, treasury inventories, library and archive materials, and notes on events in the monastery and outside life. Chronicles were usually written by monastery superiors, or special chroniclers chosen from among the monks and nuns of a given monastery, referred to as "chronologists."

\section{Monastery Chronicles as Historical Documents}

Chronicles were only intended for internal use, and all events important to the life of a given monastery community — both good and bad-were recorded therein. ${ }^{2}$ This is why monastery chronicles, just like official government documents and privileges, can be considered credible source materials-especially if they were updated constantly, which was by no means the norm.

Monastery chronicles contain a plethora of information on monastery life, political matters, culture, social customs, mentality, and even Jews. Many manuscripts have been preserved; and of these, many have not been thoroughly studied by historians, and are certainly not being used by Jewish Studies scholars. This is probably due to the difficulty involved in accessing these chronicles, which are kept in monastery archives, are not always inventoried, and are rarely made fully available to a large body of scholars. In the nineteenth century, the archives of inactive monasteries were transferred to state archives. However, these materials were often damaged or incomplete. Of course, many chronicles have been destroyed as a result of the numerous cataclysms that have haunted Polish lands over the years, including two world wars. Yet many monastery chronicles have survived-some in the form of manuscripts, some in the form of print materials-and have been published regularly since the end of the

${ }^{1}$ Hieronim Eugeniusz Wyczawski, Przygotowanie do studiów $w$ archiwach kościelnych (Kalwaria Zebrzydowska, 1989), 305-306.

${ }^{2}$ Małgorzata Borkowska, "Latanie pamięci, czyli rzecz o klasztornym kronikarstwie retrospektywnym," Znak 480 (1995), 109. 
nineteenth century (except for during the two world wars and in the People's Republic of Poland). Publication resumed after 1989, and became large-scale after 2000. Particularly relevant are the Kroniki Staropolskie [Old Polish Chronicles], a series published by the Poznań Municipal Publishing House. Furthermore, several monastery chronicles have been digitized, especially those previously published between the end of the nineteenth century and the beginning of the twentieth century. ${ }^{3}$

There are relatively few publications on the subject of monastery chronicles or their chroniclers. Among them, particularly worthy of mention are the works of Karol Górski, Małgorzata Borkowska, and Karolina Targosz. In the book, Piórem zakonnicy: Kronikarki w Polsce XVII w. o swoich zakonach i swoich czasach (Kraków, 2002), Karolina Targosz wrote about women's monastery chronicles that are of particular concern to Jewish history. Waldemar Kowalski also referred to sources of this type in several articles on the conversion of Jews to Catholicism. ${ }^{4}$ Although many scholars in Poland and abroad have addressed Christian-Jewish relations in the Polish-Lithuanian Commonwealth, only few have done so with reference to monastery chronicles, such as Adam Kaźmierczyk ${ }^{5}$ and Magda Teter. ${ }^{6}$ Many others have ignored this type of sources in their work. ${ }^{7}$

${ }^{3}$ E.g., Fr. Jan Wielewicki, Dziennik spraw domu zakonnego OO. Jezuitów u św. Barbary w Krakowie od r. 1579 do r. 1599 (Kraków, 1881), VIII, 273; www.dbc.wroc.pl/dlibra/ documentadata? $\mathrm{id}=6729 \&$ from $=$ publication [retrieved: 16 Sept. 2014].

${ }^{4}$ E.g., Waldemar Kowalski, "Stopnicki rejestr konwertytów XVII-XIX w.," Nasza Przeszłość 76 (1991), 194-195, 202, 208.

5 Adam Kaźmierczyk, "Converted Jews in Kraków, 1650-1763,” Gal-Ed 21 (2007), 19, 27-28, 36, 40, 42-43; id., Rodziłem się Żydem... Konwersje Żydów w Rzeczypospolitej XVIIXVIII wieku (Kraków, 2015).

${ }^{6}$ However, more often referred to are the constitutions of bishops' synods, the pastoral letters of various prelates, and sometimes even the Lutheran chronicle. Magdalena Teter, "Jewish Conversions to Catholicism in the Polish-Lithuanian Commonwealth of the Seventeenth and Eighteenth Centuries," Jewish History 17 (2003), 257-283; ead., "The Legend of Ger Zedek of Wilno as Polemic and Reassurance," AJS Review 29 (2005), 2: 237-263; ead., Sinners on Trial: Jews and Sacrilege after the Reformation (Cambridge-London, 2011). Here I would like to thank Magda Teter for allowing me access to many of her works.

${ }^{7}$ See, e.g., Jakub Goldberg, "Poles and Jews in the 17th and 18th Centuries: Rejection or Acceptance," Jahrbücher für Geschichte Osteuropas 40 (N.F. 22) (1974), 248-282; id., "Żydowscy konwertyci w społeczeństwie staropolskim," in Anna Izydorczyk, Andrzej Wyczański (eds.), Społeczeństwo staropolskie: Studia i szkice (Warsaw, 1986), 4: 195-247; id., "Kilkakrotny chrzest żydowskiego konwertyty," in Marian Surdacki (ed.), Religie, edukacja, kultura: Księa pamiątkowa dedykowana Profesorowi Stanistawowi Litakowi (Lublin, 2002), 91-95; Judith Kalik, "Patterns of Contacts between the Catholic Church and the Jews in the Polish-Lithuanian Commonwealth: The Jewish Debts," in Adam Teller (ed.), Studies in the History of the Jews in Old Poland in Honor of Jacob Goldberg (Jerusalem, 1998), 102-122; Krzysztof Modelski, "Conversion as a Problem of Rational Choice," in Teller (ed.), Studies 


\section{Jewish Themes in Monastery Chronicles}

In this article, I will address the Jewish themes contained in around twenty monastery chronicles of various origin from the territory of the PolishLithuanian Commonwealth. These chronicles were written in Latin and Polish in the seventeenth and eighteenth centuries, and were published between the end of the nineteenth century and the beginning of the twenty-first century. They detail the history of the Benedictine sisters, Bernardines and Bernardine sisters, Bridgettines, Dominican sisters, Jesuits, Discalced Carmelites and Discalced Carmelite sisters, White Friars (Carmelites [Polish: karmelici trzewiczkowi]), Poor Clares, Norbertine sisters, and Franciscans-Reformers living in monasteries located in Lesser Poland (Imbramowice, Kraków, Lublin, Radom, and Sandomierz), Greater Poland (Poznań), Mazovia (Warsaw), Lithuania (Grodno and Vilna), and Ruthenia (Lwów). Individual chronicles contain anywhere from a dozen pages to nearly five hundred. The frequency at which they mention Jews is various - sometimes not at all, sometimes on every other page (in one case). In most chronicles, however, the subject matter is marginal. ${ }^{8}$

in the History, 147-160; Bogdan Rok, "Stosunek polskiego Kościoła katolickiego do sprawy żydowskiej w I połowie XVIII wieku," in Krystyn Matwijowski (ed.), Z historii ludności żydowskiej w Polsce i na Śląsku (Wrocław, 1994), 85-97.

${ }^{8}$ Akta klasztoru pp. Franciszkanek s. Jędrzeja w Krakowie elekcyi ksień i innych potocznych dziejów tegoż klasztoru składające się od r. 1784-go [do r. 1850], Archiwum SS. Klarysek w Krakowie [Archive of the Poor Clares in Kraków], call no. A 37; Jan Wielewicki, Dziennik spraw domu zakonnego OO. Jezuitów u ś. Barbary w Krakowie od r. 1579 do r. 1599 (wtacznie), [vol. 1], (Kraków, 1881), (Scriptores Rerum Polonicarum. Tomus septimus); id., Dziennik spraw domu zakonnego OO. Jezuitów u św. Barbary w Krakowie od r. 1600 do r. 1608 (wtacznie), [vol. 2], (Kraków, 1886), (Scriptores Rerum Polonicarum. Tomus decimus); id., Dziennik spraw domu zakonnego OO. Jezuitów u św. Barbary w Krakowie od r. 1609 do r. 1619 (włacznie), [vol. 3], (Kraków, 1889), (Scriptores Rerum Polonicarum. Tomus decimus quartus); id., Dziennik spraw domu zakonnego OO. Jezuitów u św. Barbary w Krakowie od r. 1620 do r. 1629 (włącznie), vol. 4 (Kraków, 1899), (Scriptores Rerum Polonicarum. Tomus decimus septimus); "Rozbiór rękopiśmiennej księgi: Zapisy Karmelitanek Bosych we Lwowie," ed. Izydor Szaraniewicz, Przewodnik Naukowy i Literacki 13 (1885), 5: 403-411; 6: 495-509; 7: 591-604; [Rafał Józef Kalinowski], Klasztory Karmelitanek Bosych w Polsce, na Litwie i Rusi. Ich poczatek, rozwój i tułactwo w czasie rozruchów wojennych w XVII wieku. Rzecz osnuta na kronikach klasztornych, vol. 1 (Kraków, 1902); "Kronika klasztoru Panien Bernardynek warszawskich," ed. Stanisław Chodyński, Kwartalnik Teologiczny 6 (1907), 1-4: 38-90; "Zapiski historyczne benedyktynek radomskich oraz materiały do kultu Magdaleny Mortęskiej," ed. Anna Małgorzata Borkowska, in Karol Górski, Anna Małgorzata Borkowska, Historiografia zakonna a wzorce świętości w XVII w. (Warsaw, 1984), 321; Dzieje kapitularne zakonnic świętej matki Brygitty konwentu grodzieńskiego, eds. Małgorzata Borkowska, Krzysztof Obremski (Toruń, 2001); Kroniki Benedyktynek poznańskich, eds. Małgorzata Borkowska, Wanda Karkucińska, Jacek Wiesiołowski (Poznań 2001); Kronika poznańskich Karmelitów Bosych, ed. Piotr Franciszek Neumann (Poznań, 2001); Kroniki Bernardynów poznańskich, eds. Salezy 
The chronicles address a variety of issues related to Jews, who are often referred to as "infidels." The majority of these references concern their conversion to Christianity. To a lesser extent, they concern alleged ritual murders, the profanation of hosts, economic events, cataclysms, thefts, fights, other crimes, the passage of foreign armies, and religious, moral, and social issues. Much less attention is devoted to Jewish buildings, streets, cemeteries, and court hearings.

\section{Converts}

As aforementioned, Jews were recorded in monastery chronicles mainly as converts to Christianity. Six of the books used for this study mention their baptisms. Most frequently, the references are short, and contain information on the dates of ceremonies, new names of neophytes, their age, names of witnesses and priests, and sometimes the number of Christians, clergymen, and distinguished guests present. There are also entries that simply record the occurrence of a baptism without any further information. For example, "We baptized ... a certain Jew as soon as we thoroughly taught him about the mysteries of the faith." Significantly

Bogumił Tomczak, Jacek Wiesiołowski (Poznań, 2002); "Kronika bernardynek świętomichalskich w Wilnie,” ed. Maria Kałamajska-Saeed, Nasza Przeszłość 101 (2004), 331-435; Kronika jezuitów poznańskich (młodsza), vol. 1: 1570-1653, eds. Ludwik Grzebień, Jacek Wiesiołowski (Poznań, 2004); Kroniczka rezydencji Karmelitów Trzewiczkowych w Poznaniu przy kościele Najświętszej Krwi Pana Jezusa na ul. Żydowskiej, ed. Jacek Wiesiołowski (Poznań, 2005); Kronika Benedyktynek Sandomierskich czyli Dzieje klasztoru sandomierskiego od roku 1615. 30 października. Spisane w roku 1763 za przełożeństwa P. Maryanny Siemianowski ksieni 13, vol. 1, ed. Anna Szylar (Sandomierz, 2005); Kronika Reformatów poznańskich, eds. Jacek Wiesiołowski, Salezy Bogumił Tomczak, Grzegorz Antoni Wiśniowski (Poznań, 2006); Kronika fundacyjna klasztoru mniszek zakonu kaznodziejskiego na Gródku w Krakowie (1620-1639). "Kronika abo opisanie postępków i zachodów około fundowania konwentu," introduction and ed. Anna Markiewicz (Kraków, 2007); Jan of Komorów, "Krótka Kronika Zakonu Braci Mniejszych. Cz. 1," trans. Kazimierz Żuchowski, Przeglad Kalwaryjski 11-12 (2007/2008), 297-406; id., "Krótka Kronika Zakonu Braci Mniejszych. Cz. 2 (1453-1517)," trans. Kazimierz Żuchowski, Przeglad Kalwaryjski 13 (2009), 429-591; id., "Krótka Kronika Zakonu Braci Mniejszych. Cz. 3 (1517-1536)," trans. Kazimierz Żuchowski, Przegląd Kalwaryjski 14 (2010), 379-480; Kronika bernardynek lubelskich 1618-1885, ed. Anna Szylar (Lublin, 2009); "Kronika Ojca Cypriana Damirskiego OFM,” trans. Kazimierz Żuchowski, Przeglad Kalwaryjski 15 (2011), 367-490; Metryka brygidek lubelskich, introduction and ed. Jarosław R. Marczewski (Lublin, 2011); Zofia Grothówna, Kronika klasztorna sióstr norbertanek w Imbramowicach 1703-1741, eds. Włodzimierz Bielak, Waldemar Żurek (Kielce, 2011); Kronika Klasztoru Karmelitanek Bosych pw. św. Józefa w Lublinie, ed. Czesław Gil (Poznań, 2012).

${ }^{9}$ Kronika jezuitów poznańskich, 16. Similar laconic references to baptisms of Jews can be found here: ibid., 59, 61, 142, 148. 
longer descriptions mention not only the baptism ceremony, but also the process leading up to it, which usually involved some spectacular conversion. One example is the baptism of Ida, the daughter of Abram, a rabbi from Poznań, which is described in a 1788 chronicle of the Poznanian Franciscans-Reformers. Before being baptized, she was the wife of Jakub, son of Józef, a melamed from Königsberg in Prussia. Their relationship, which was made official in Kobylin, lasted fifteen years, and yielded four children: three sons and one daughter. The couple lived in the Jewish neighborhood in Śródka near Poznań (it became a part of Poznań in 1800), from which she later escaped to become baptized. Initially, she found refuge with local Śródka tertiaries Aleksandra and Petronella Boińska, who then transferred her into the hands of Franciscans-Reformers brothers Bartłomiej Żołądkiewicz and Elzeariusz Albrecht. For seven weeks, they taught her the principles of the Christian faith, after which she was baptized by the guardian of the Poznanian convent. At her baptism, which took place in the Oratory of Saint Philip Neri, she received the name Brygida Tekla in the presence of her godparents, one of which was Sebastian Mejerer, a Poznanian alderman and councilor, who on behalf of the mayor gave her the surname Michalska. Also present were Zuzanna Barańska, Norbert Roze, Marianna Smolińska, Nepomucen Kaczkiewicz, Agata Kulerówna, Antoni Kaczkiewicz, Regina Żołądkiewiczówna, and other "gathered people." Her godparents offered her financial support in the form of 607 Polish złotys. ${ }^{10}$

A chronicle of the Sandomierz Benedictine Sisters also records another baptism which took place under dramatic circumstances. On 28 August 1763, a very young Jewish boy was brought to the Benedictine Sisters convent in Sandomierz, most likely to be baptized. At news of this, the local Jews insisted to the prelatess Marianna Siemianowska that the child be returned due to his young age. The prelatess did not want to do this, and instead of giving him to the Jews, she gave him to an unnamed woman in local distillery. That night, the child was taken to the local monastery of the Franciscans-Reformers. This act obviously outraged the Jews, who continued to demand that the boy be returned. However, in accordance with an order from an unnamed priest and royal custodian ${ }^{11}$ who was a member of the chapter, it was determined

${ }^{10}$ Kronika Reformatów poznańskich, 175-176.

${ }^{11}$ This is probably Jan Nepomucen Radwański, who from 1753 was an assistant custodian, and from 1769 an archdeacon and Sandomierz official. 
that, because the boy was too young to speak for himself, two cordons should be formed. One would consist of the Jews, and the other of the Catholics. Whichever side he turned to would be the one with which he would remain. In spite of his father's persuasion, he turned to the Catholics, and was subsequently transferred to the Franciscans-Reformers for study. The boy was named Michał Józef Antoni, and baptized on 20 January 1764 in the Benedictine Sisters Church of Sandomierz. The baptism was performed by assistant custodian Jan Nepomucen Radwański, and the first pair of godparents were Benedictine prelatess Marianna Siemianowska, and a treasurer named Masalski, about whom nothing else is known. ${ }^{12}$

Of the 44 baptisms of persons of Jewish origin aged 7 to 79 recorded in monastery chronicles from the period of 1576-1796, 17 were men, 10 were women, and 17 were children (10 boys and 7 girls). In these records, 6 of the men and boys, and 14 of the women and girls were listed by name ( 9 of the women and girls were named Marianna). These names have been provided here in two tables, with the women in Table 1, and the men in Table 2. Interestingly, we know the ages of all 7 girls: 7, 11, 12, 13, two were 15, and the age of the seventh girl is listed as "a dozen or so."13 (According to standards of that time, the 12-, 13-, and two 15-year-old girls may be treated as women.)

With respect to conversions, it is worth drawing attention to an entry in one of the chronicles of the Poznanian Bernardines, which indicates that in 1751, Jews organized missions among Christians in Vilna in an effort to convert them to Judaism. As a result, "three Christian women were drawn to the Talmud."14

${ }^{12}$ Kronika Benedyktynek Sandomierskich, 48, 56.

${ }^{13}$ Ibid., 46-47, 53, 56, 69-71, 107-108, 121-122, 124, 141, 144; Kronika jezuitów poznańskich, 16, 40-41, 59, 61, 115, 142, 148, 153, 286, 310-311, 316, 336; Kronika poznańskich Karmelitów Bosych, 19; Kronika Reformatów poznańskich, 175, 179-180, 183-184, 189-190; Grothówna, Kronika, 55-56, 209; Wielewicki, Dziennik spraw domu zakonnego OO. Jezuitów, vol. 4, pp. 313, 329; "Zapiski historyczne benedyktynek radomskich," 321.

14 “Zaginiony rękopis kroniki domowej,” in Kroniki Bernardynów poznańskich, 366. 
Table 1. Names of baptized Jewish women listed in the chronicles used for this study (in chronological order).

\begin{tabular}{|c|c|c|c|c|c|}
\hline No. & $\begin{array}{c}\text { Jewish name } \\
\text { or pre-baptism } \\
\text { name } \\
\end{array}$ & $\begin{array}{c}\text { Christian } \\
\text { name(s) and } \\
\text { surname } \\
\end{array}$ & $\begin{array}{l}\text { Place of } \\
\text { baptism }\end{array}$ & $\begin{array}{l}\text { Date of } \\
\text { baptism }\end{array}$ & Source \\
\hline 1 & $\begin{array}{l}\text { Anna [Hebr. } \\
\text { Chana] }\end{array}$ & Marianna & Radom & 9 Oct. 1707 & $\begin{array}{l}\text { "Zapiski historyczne } \\
\text { benedyktynek radom- } \\
\text { skich," } 321 .\end{array}$ \\
\hline 2 & & $\begin{array}{c}\text { Katarzyna } \\
\text { Helena Cza- } \\
\text { jowska (from } \\
\text { Czajowice) }\end{array}$ & $\begin{array}{l}\text { Imbramo- } \\
\text { wice }\end{array}$ & 16 May 1712 & $\begin{array}{c}\text { Grothówna, Kronika, } \\
55-56 .\end{array}$ \\
\hline 3 & & Zofia & Radom & 1714 & $\begin{array}{c}\text { "Zapiski historyczne } \\
\text { benedyktynek radom- } \\
\text { skich," } 321 .\end{array}$ \\
\hline 4 & & $\begin{array}{c}\text { Anna Justyna } \\
\text { from the } \\
\text { Rzeżuśnia } \\
\text { brewery } \\
\end{array}$ & $\begin{array}{l}\text { Imbramo- } \\
\text { wice }\end{array}$ & 7 Aug. 1727 & $\begin{array}{c}\text { Grothówna, Kronika, } \\
209 .\end{array}$ \\
\hline 5 & & Marianna & $\begin{array}{c}\text { Skórzewo, } \\
\text { Poznań } \\
\text { district }\end{array}$ & 1748 & $\begin{array}{l}\text { Kronika Reformatów } \\
\text { poznańskich, } 179 .\end{array}$ \\
\hline 6 & & $\begin{array}{c}\text { Marianna } \\
\text { Urszula }\end{array}$ & Sandomierz & 26 July 1763 & $\begin{array}{c}\text { Kronika Benedyktynek } \\
\text { Sandomierskich, 46-47. }\end{array}$ \\
\hline 7 & & $\begin{array}{c}\text { Marianna } \\
\text { Apolonia }\end{array}$ & Sandomierz & 18 Dec. 1763 & Ibid., 53. \\
\hline 8 & & $\begin{array}{l}\text { Marianna } \\
\text { from } \\
\text { Rzeczyca }\end{array}$ & Sandomierz & 2 Nov. 1764 & Ibid., 69-70. \\
\hline 9 & & $\begin{array}{c}\text { Marianna } \\
\text { from Ossolin }\end{array}$ & Sandomierz & 14 Nov. 1764 & Ibid., $69,71$. \\
\hline 10 & & $\begin{array}{l}\text { Marianna } \\
\text { Scholastyka } \\
\text { from Łagów }\end{array}$ & Sandomierz & 25 Mar. 1767 & Ibid., 107-108. \\
\hline 11 & & $\begin{array}{l}\text { Konstancja } \\
\text { Józefa Woj- } \\
\text { ciechowska } \\
\end{array}$ & Sandomierz & 27 Jan. 1769 & Ibid., 121-122. \\
\hline 12 & & $\begin{array}{c}\text { Marianna } \\
\text { Kunegunda } \\
\text { Franciszka } \\
\text { from Garbacz } \\
\end{array}$ & Sandomierz & 30 July 1769 & Ibid., 124. \\
\hline 13 & & Marianna & $\begin{array}{l}\text { Bidziny, } \\
\text { Opatów } \\
\text { district }\end{array}$ & 28 Sept. 1771 & Ibid., 141, 144. \\
\hline 14 & $\begin{array}{c}\text { Ida [Hebr. } \\
\text { Jehudit] } \\
\text { Abramówna } \\
\text { [daughter of } \\
\text { Abram] }\end{array}$ & $\begin{array}{c}\text { Brygida Tekla } \\
\text { Michalska }\end{array}$ & Poznań & 28 Sept. 1788 & $\begin{array}{c}\text { Kronika Reformatów } \\
\text { poznańskich, } 175 \text {-176. }\end{array}$ \\
\hline
\end{tabular}


Table 2. Names of baptized Jewish men listed in the chronicles used for this study (in chronological order).

\begin{tabular}{|c|c|c|c|c|c|}
\hline No. & $\begin{array}{c}\text { Jewish name } \\
\text { or pre-baptism } \\
\text { name }\end{array}$ & $\begin{array}{c}\text { Christian } \\
\text { name(s) and } \\
\text { surname }\end{array}$ & $\begin{array}{c}\text { Place } \\
\text { of baptism }\end{array}$ & $\begin{array}{c}\text { Date } \\
\text { of baptism }\end{array}$ & Source \\
\hline 1 & Michał & Poznań & 8 Dec. 1623 & $\begin{array}{c}\text { Kronika poznańskich } \\
\text { Karmelitów Bosych, 19. }\end{array}$ \\
\hline 2 & $\begin{array}{c}\text { Lewkowicz } \\
\text { [son of Jehuda- } \\
\text { Lejb] }\end{array}$ & Michał & Kraków & 9 Sept. 1629 & $\begin{array}{c}\text { Wielewicki, Dziennik } \\
\text { spraw domu zakonnego } \\
\text { OO. Jezuitów, vol. 4, } \\
\text { p. 329. }\end{array}$ \\
\hline 3 & & $\begin{array}{c}\text { Teodor } \\
\text { Desau }\end{array}$ & Poznań & 8 Jan. 1754 & $\begin{array}{c}\text { Kronika Reformatów } \\
\text { poznańskich, 180. }\end{array}$ \\
\hline 4 & $\begin{array}{c}\text { Michał Józef } \\
\text { Antoni }\end{array}$ & Sandomierz & 20 Jan. 1764 & $\begin{array}{c}\text { Kronika Benedyktynek } \\
\text { Sandomierskich, 56. }\end{array}$ \\
\hline 5 & $\begin{array}{c}\text { Jan Marcin } \\
\text { Pruski }\end{array}$ & Poznań & 11 Nov. 1769 & $\begin{array}{c}\text { Kronika Reformatów } \\
\text { poznańskich, 183-184. }\end{array}$ \\
\hline 6 & $\begin{array}{c}\text { Beniamin } \\
\text { Izrael from } \\
\text { Czarnków }\end{array}$ & $\begin{array}{c}\text { Szymon } \\
\text { Chęciński }\end{array}$ & Poznań & 26 Oct. 1796 & Ibid., 189-190. \\
\hline
\end{tabular}

\section{Records of Alleged Profanations of Hosts}

In addition to conversions, there are many references in monastery chronicles to alleged profanations of hosts and ritual murders that involve Jews. Most of them are found in a chronicle of the Poznanian White Friars entitled "Diariusz Rezydencji Przenajświętszej Krwi Chrystusa," which was written between 1754 and 1769 by successive leaders of their residence, beginning with Fr. Anastazy of St. Brocard, lecturer of holy theology, and ending with Fr. Arnold, syndic of the Greater Poland Province. This residence is closely tied to Jan Długosz's legend concerning hosts allegedly profaned by Poznanian Jews and then miraculously found in a meadow near the city in August 1399. The authors of subsequent versions of the legend attempted to make it more credible by investigating factual and topographic details. As a result of this research, a building was found on Żydowska [Jewish] Street in Poznań where not one, but three hosts were supposedly punctured, with blood gushing therefrom. In the mid-seventeenth century, the Carmelites received consent from King Jan Kazimierz to turn the building into an oratory; and at the beginning of the eighteenth century, the Church of the Most Holy Blood of Christ was erected in its place. ${ }^{15}$

${ }^{15}$ Jacek Wiesiołowski, "Wstęp,” in Kroniczka rezydencji Karmelitów, V-VII. 
The introduction of the above-mentioned "Diariusz Rezydencji" contains a two-page text entitled "Krótkie opisanie wzniesienia kaplicy Przenajświętszej Krwi Chrystusa Pana przy ulicy Żydowskiej w Poznaniu," which describes in detail the profanation of the three hosts allegedly committed by rabbis with knives in the building of the Świdwa family on 15 August 1399. It then refers to successive decrees of the Roman Curia and Poznanian Bishop Mikołaj Stanisław Święcicki that confirm the occurrence of the profanation, and allow special celebration of the Feast of Corpus Christi at the site of the transgression. ${ }^{16}$ The chronicle later describes how one of the oratory's residents, Fr. Dionizy of St. Anthony, found a well in which the Jews allegedly put the hosts. The well was then cleaned, filled with water, and the sick that drank from it regained their health. ${ }^{17}$ In 1730, another leader of the oratory, Fr. Bartłomiej of St. Adrian, recommended that "the story of how the Most Holy Hosts were punctured, and the execution of the Jewish culprits and the sacrilegious woman" who sold them the hosts be painted at the occasion of the building's renovation. This greatly aggravated the local Jewish community, which through the protection of magnates attempted to persuade the Carmelites to remove the painting, as it was causing peasants and juveniles to attack Jews. However, the provincial of the order, Fr. Erazm, did not agree. What is more, in the mid-eighteenth century, the Discalced Carmelites decided that every year, on the Friday before the Sunday on which the dedication of the Poznań cathedral is celebrated (i.e. in late August), they would observe the "recollection of the Puncturing of the Three Most Holy Hosts." In 1750, Fr. Arnold, syndic of the Greater Poland Province, persuaded the local Jewish community to provide the Carmelites with adequate quantities of fish and spices, also on an annual basis, as a form of "payment for the crime" that they had committed. This festive "recollection" lasted for eight days, and, according to the chronicle, was observed at least until 1768. Furthermore, one of the oratory's residents, Fr. Paweł of St. Thomas, erected a portico in front of it in 1751. As the chronicle emphasized, this prevented the Jews from seeing inside. ${ }^{18}$

References to this legend and the scene of the alleged profanation of the three hosts, as well as an anonymous work on the subject published in A4 format and entitled "Hystorya o SS. Trzech Hostyach w Poznaniu" can

\footnotetext{
${ }^{16}$ Kroniczka rezydencji Karmelitów, 1-11.

17 Ibid., 14.

18 Ibid., 18-19, 23, 35, 52-53, 76, 146.
} 
also be found in the chronicle of the Poznanian Franciscans-Reformers. ${ }^{19}$ Furthermore, in the 1571 entry of the Poznanian Jesuits chronicle, among stories about the travels of the order's provincial, Fr. Wawrzyniec Maggio (together with Fr. Jakub Wujek, Fr. Szymon Wysocki, and two brothers from Warsaw, where they were visiting Apostolic Nuncio Giovanni Francesco Commendone), is a passus that reads, "on the way to Sochaczew, they learned that it was true what had been said about the miracles that happened as a result of Most Holy Eucharist being stabbed by the Jews, who were exposed and killed by the blood gushing from the punctured Host." ${ }^{20}$ This is probably a reference to events that took place in Sochaczew in 1556, of which Jews were accused by Nuncio Alojzy Lippoman. ${ }^{21}$

\section{References to Alleged Ritual Murders}

The monastery chronicles also contain brief accounts of allegations of ritual murders against Jews. For example, a Bernardine chronicle written by Jan of Komorów [Jan z Komorowa] contains a brief reference to dramatic events that took place in Lublin in 1581. Allegedly, a woman sold her son to Jews, who then "spilled his blood," and many of whom were later caught. The chronicle then goes on to state that "their sacrifices shall be a propitiation of God and men." 22 What is interesting is that this is the only known reference to this event, as it has not at all been recorded by historians studying allegations of ritual murders against Jews and profanation of hosts in the Polish-Lithuanian Commonwealth. It is also argued that what is written in the chronicle actually refers to events known from other sources that took place in Lublin either 2 years earlier or 11 years later. ${ }^{23}$

Furthermore, well known is a 1736-1740 trial of Jews accused of ritual murder in Poznań. It was recorded in two monastery chronicles of the

${ }^{19}$ Kronika Reformatów poznańskich, 31, 32, 111.

${ }^{20}$ Kronika jezuitów poznańskich, 9.

${ }^{21}$ For more on the accusations and trial in Sochaczew in 1556, see also Hanna Węgrzynek, “Czarna legenda” Żydów: Procesy o rzekome mordy rytualne w dawnej Polsce (Warsaw, 1995), 51ff., $182 \mathrm{ff}$.

${ }_{22}$ Jan of Komorów, “Krótka Kronika Zakonu Braci Mniejszych. Cz. 3,” 473.

${ }^{23}$ Joseph Perles, Geschichte der Juden in Posen (Breslau, 1865), 82-84, 98-105; Węgrzynek, "Czarna legenda" Żydów, 186; Zenon Guldon, Jacek Wijaczka, Procesy o mordy rytualne w Polsce w XVI-XVIII wieku (Kielce, 1995), 34; Anna Michałowska-Mycielska, The Jewish Community: Authority and Social Control in Poznan and Swarzędz 1650-1793, trans. Alicja Adamowicz (Wrocław, 2008), 19. 
Bernardines and Discalced Carmelites, and compiled in detail by historians Majer Bałaban, Joseph Perles, Zenon Guldon, Jacek Wijaczka, and Anna Michałowska-Mycielska. Although both chronicles contain very laconic information, they supplement other source materials collected by these historians on the same subject, despite an erroneous accusation date (1735) in the Bernardine chronicle. ${ }^{24}$

\section{Economic Activity of Jews}

The chronicles of Catholic monasteries also contain a wealth of information on the economic activity of Jews, including their trade practices, crafts, financial transactions, and church offerings. Recorded in 1755 in the chronicle of the Discalced Carmelites is part of the last will and testament of a rich Portuguese Jew named Pirita or Pinta (possibly a member of the famous Pinto family), who died in Amsterdam and left behind a great fortune. He willed it to various secular, Christian, and Jewish institutions, as well as to his family, his servants, and the poor in Amsterdam, the Hague, and Jerusalem. For example, the States General of the Netherlands received half a million guldens (and additionally one and a half million guldens for wars), all Christian churches and chapels in the Hague and Amsterdam received 100,000 guldens, the leaders of the Jewish city in Jerusalem received one million, the Portuguese synagogue in Amsterdam received one and a half million, the German synagogue received fifteen thousand, his wife received three million and also all palaces and gardens in the above-mentioned cities, as well as his seven servants, each received ten thousand. Significant is the following comment, which was written under the will in the chronicle:

O dear Lord, what a wealth! Yet he who is devoid of the treasure of real faith shall be the greatest pauper under the Prince of Darkness. Provide us with real riches, that your holy virtues may remain with us now and forever. ${ }^{25}$

As we can see, the citation contains no real words of praise or support, only jealousy and condemnation. Unfortunately, we know of no other

${ }^{24}$ Kronika poznańskich Karmelitów Bosych, 236; Kroniki Bernardynów poznańskich, 276-277; Majer Bałaban, "Arje Lejb Kalahora (Do procesu poznańskiego w latach 17361740)," in id., Studja historyczne (Warsaw, 1927), 141-150; Perles, Geschichte der Juden, 8284, 98-105; Guldon, Wijaczka, Procesy o mordy rytualne, 69-70; Michałowska-Mycielska, The Jewish Community, 19.

${ }^{25}$ Kronika poznańskich Karmelitów Bosych, 306. 
links between the Poznanian Carmelites and the Portuguese Jews living in the Netherlands.

The chronicles in question also contain references to indigenous Jewish merchants who traded near churches, as was the case in Poznań. On 18 December 1764, with the consent of the provincial of the White Friars, Fr. Konstantyn of St. Lawrence, the Poznanian burgrave, Kazimierz Miedźwiecki ${ }^{26}$ concluded a contract with the Jews, on the basis of which they could conduct trade under the roof opposite the Church of the Most Holy Blood of Christ on the condition that each of them offered a concretion of melted tallow to the Friars on All Saints' Day every year. In case the concretions were not offered, the Jews were to be prohibited from trading there. On 23 March 1768, this offering was changed to two ducats intended to fund the lighting of the church-one paid in March, and the second in September. ${ }^{27}$

The chronicles also contain information about individual Jewish craftsmen, lease administrators, and doctors that the nuns and monks came into contact with. Among them were saddlers, bricklayers, and lease administrators in Poznań, tavern keepers in Grodno, and keepers of a brewery with a malt production facility, a beef production facility, and a granary in the estate of the Lublin Bernardine Sisters in Rozkopaczew (in the Lubartów district) ${ }^{28}$ Clergymen were also forced to use the services of Jewish innkeepers when travelling. An interesting description of accommodation in an inn comes from the chronicle of Discalced Carmelite Sisters in Lublin. In mid-September of 1655, some nuns who had come down from Lithuania were heading toward Kraków in an effort to escape the Russian-CossackSwedish invasion. The first accommodation site they found was in an old inn located in Abramowice near Lublin, which they later described as follows: "We stayed in the cramped room of a Jewish innkeeper, and when we laid down, we could not turn around, because we were nearly laying on top of one another. Other accommodation sites were ugly, and so full of lice, frogs, and crickets that they were jumping over our heads and mouths, ... which, after having left our monastic cells, was a burden to us.”29

${ }^{26}$ It is worth adding that this burgrave translated a work by Tomasz Treter on the three hosts and a book on miracles in the Church of Corpus Christi in Poznań into Polish. Kroniczka rezydencji Karmelitów, 191, n. 77.

${ }^{27}$ Ibid., 40, 106, 128, 148, 186.

${ }^{28}$ Ibid., 69, 158-159; Dzieje kapitularne zakonnic świętej matki Brygitty, 202; Kronika bernardynek lubelskich, 126, 135, 207.

${ }_{29}$ Kronika Klasztoru Karmelitanek Bosych, 105-106, 109. 
Consecrated persons were also not afraid to employ Jews in various capacities in monasteries and their estates. For example, on 6 November 1729, a prelatess and chronicle author of the Norbertine Sisters in Imbramowice hired Jewish glassmakers from Wolbrom ${ }^{30}$ to install windows in a new building that was part of a monastery grange in Trzyciąż (Olkusz district). Jesuits and Discalced Carmelite Sisters in Poznań were also visited by Jewish doctors. In December of 1647, an official and land steward of the Diocese of Greater Poland named Branecki sent his presbyter to the rector of the Poznanian Jesuits to demand the release of priests who had maintained friendly relations with an anonymous Jewish doctor against the bull of Pope Gregory XIII. He was told that "it is impossible to demand public examination of conscience from these figures and punish them, as is the case with those who stand judged in the sacrament of atonement. Moreover, the case of the bull cannot be invoked, as it refers to 'reserved sin."'31 The fact that such contacts between Jews and the Polish clergy were not isolated phenomena is further evidenced by another example from Poznań. Discalced Carmelite Barbara of the Blessed Sacrament, i.e. Teofila Zadzikowa née Kretkowska (1609-1670), whose life was recorded by Konstancja Iżycka, a nun of the order, was in her final days visited by a Jewish doctor from Poznań, who took no money for his medical services, and "cared for her health as if he were her own father." 32

Monasteries also invested their money in various synagogues for socalled wyderkafs, which were in fact a hidden form of loan for Jews with a predetermined interest rate. Jews willingly took loans from church institutions, as they were cheaper and easier to obtain than those available on the free market. ${ }^{33}$ This is evidenced by a chronicle from the Bernardine Sisters in Vilna. For example, on 25 October 1694, the sisters invested 6,000 Polish złotys in the Vilna kahal, which was granted to them by Józef Hliniecki, the head of the national guard (wojski) in Starodub, most likely with a 7\% interest rate in accordance with "church custom."

${ }^{30}$ Grothówna, Kronika, 225.

${ }^{31}$ Kronika jezuitów poznańskich, 430-431.

${ }^{32}$ Karolina Targosz, Piórem zakonnicy: Kronikarki w Polsce XVII w. o swoich zakonach i swoich czasach (Kraków, 2002), 112, 114.

${ }^{33}$ See also Stefan Gąsiorowski, "Wierzytelności dominikanów lwowskich u Żydów z terenu Rusi Czerwonej w 2. połowie XVII i w XVIII wieku," in Anna Markiewicz, Marek Miławicki (eds.), Dominikanie na ziemiach polskich w epoce nowożytnej (Kraków, 2009), 193-213. 
In 1725 , the loan grew to 8,600 złotys, from which the Bernardine Sisters only took a commission of $3.5 \%$ until 1765 (i.e. 301 złotys). ${ }^{34}$ The situation was similar in Poznań. In 1680, an otherwise unknown nobleman named Noskowski willed 1,000 złotys to the Jews in Poznań for the Franciscans-Reformers monastery. Nevertheless, due to urgent need, the Jews immediately paid the money to the guardian of the monastery. ${ }^{35}$ In 1762, Fr. Arnold, syndic of the White Friars of the Greater Poland Province, granted "1) 570 florins to the synagogue in Poznan, 2) 900 florins, i.e. 50 ducats, to the house of unfaithful Prochowiak, 3 ) an income of 1,500 florins, from which the Jewish merchant can withdraw a sum of 100 annually." ${ }^{36}$ Then in 1768, the Poor Clares from Kraków took a wyderkaf from 1,000 Polish złotys that had been willed to the kahal in Pińczów. In 1800, it was discovered that the documents concerning the matter had disappeared. ${ }^{37}$

\section{Reports of Other Events}

The chronicles in question also contain various information on other important events that took place within or outside of a given monastery, such as cataclysms, crimes, beatings, daring incidents of theft, passages of foreign armies, and tributes. The Poznanian monastery chronicles contain a few references to fires in the city, especially in Jewish quarters. For instance, on 10 June 1590, the Jesuits wrote, "As a result of the recklessness of the Jews ... the third part of the city nearly burned down. All Jewish houses and 73 Christian houses were burned." ${ }^{\prime 38}$ Furthermore, on 1 June 1763 , according to a Bernardine chronicler from Poznań, "the non-Catholic Jews and their synagogue burned in the city of Kobylin [in the Krotoszyn district], whereas the houses of Catholics were untouched." 39 A fire that again raged in Poznań on the night of 3-4 August 1764 was described in two chronicles. The Bernardine version reports that:

at midnight, on 4 August, a fire broke out on Żydowska [Jewish] Street, and within 6 hours turned 76 houses into ash. Three synagogues were burned, some Jews were burned, and some who tried to save their possessions were crushed by the

\footnotetext{
34 "Kronika bernardynek świętomichalskich," 397.

${ }^{35}$ Kronika Reformatów poznańskich, 134.

${ }^{36}$ Kroniczka rezydencji Karmelitów, 27-28.

${ }^{37}$ Akta klasztoru pp. Franciszkanek, 14.

${ }^{38}$ Kronika jezuitów poznańskich, 97.

39 Jan Kamieński, ["Kronika poznańska”], in Kroniki Bernardynów poznańskich, 284.
} 
crumbling buildings. If the wind had not turned to Grochowe Łąki, the fire would have burned the entire city down, as oil, tallow, and other flammable materials fueled it immensely. ${ }^{40}$

The Carmelite version reads:

On 3 August, at night, after 11 p.m., a great fire broke out on Żydowska Street. The reason for this was the foolhardy faith of the Jews, who are not allowed to extinguish sabbatical candles. The fire consumed over 200 stone and wooden houses, and 2 synagogues. The church and the monastery of the Very Reverend Dominican fathers were in great danger due to the strong wind that brought the fire in their direction. Because it was the Sabbath, the Jews did nothing to help extinguish the fire, except for a few who were forced by soldiers. They saved only their own possessions. After the fire, some stayed in Poznań and found help from Christians, but very many spread to the outskirts of the city, and neighboring cities and villages. ${ }^{41}$

It seems that the Carmelite version of this event is more credible than the Bernardine version. It is rich in detail and-possibly-eyewitness accounts due to the fact that their Poznanian residence was located on Żydowska Street. It contains not only a basic account of the conflagration, but an indication of the cause, and a description of the victims.

Later in the same chronicle, we find further information on Jews and fires. Again, in September of 1764, two more fires broke out on Żydowska Street. Then, on 19 July of the next year, Wawrzyniec Pachurski, a resident of the St. Adalbert Suburb of Poznan, helped extinguish a fire in the apartment of a Jewish family that broke out during the evening meal on the Sabbath. The Jews did not want to prevent the disaster themselves "due to their frivolous practice," so they called him to help, and "promised a reward." ${ }^{42}$ Another event took place on Żydowska Street on 17 October 1766 around 5 p.m. Then, "opposite the synagogue, in a house that had been newly rebuilt after a great fire, the chimney began to burn. Because of the approaching Sabbath, and thanks to the efforts of ... the Jews, who flocked to fill it with water, the fire was extinguished." 43 According to the chronicle, further struggles with fire involving Poznanian Jews also took place on 8 and 16 November 1766, and 17 and 18 April of 1767. The losses of Christians in these and other fires were significant, which prompted the public prosecutor (probably Dionizy Szpern) to organize an inspection

\footnotetext{
40 "Zaginiony rękopis kroniki domowej," 370.

${ }^{41}$ Kroniczka rezydencji Karmelitów, 34-35.

${ }^{42}$ Ibid., 49.

${ }^{43}$ Ibid., 80.
} 
team, consisting of two Christian masonry experts and two Jews, to order demolition of any suspect chimneys. The chronicle reads, "If there were any visible beams in a chimney, they were immediately removed by craftsmen, and cleaning and repair of the chimneys was recommended, under threat of the full declared punishment for resistant persons." ${ }^{44}$ But these legitimate operations did not eliminate all fire hazards, as further fires resulted from human error on 9 and 10 April 1768, and 13 December 1769.45

The Jewish neighborhood in Poznań was also plagued by other cataclysms such as floods, and-beginning from mid-1768 - passages of Russian soldiers, who demanded food, billets, entertainment, and high tributes. The soldiers robbed the city, and left it in a state of financial ruin. Furthermore, according to the chronicle, the magistrate took no corrective measures. It was not until 11 July 1768 that the local Jews hired 15 people, both Christians and Jews, to patrol the streets and maintain order, thanks to which the Church of the White Friars "was safe from looters." ${ }^{46}$ Unfortunately, deficiencies in the kahal coffers caused delays in tax payments, and the municipal financial administrator cut both the Jews' and the Carmelites' water off on 8 November 1768. It was turned back on two days later after the Jewish community paid the due amount. ${ }^{47}$

Monastery chronicles contain abundant information on murders, fights, and thefts related to Jews. As Jan of Komorów wrote in the chronicle of the Franciscan order, the crusade against the Turks and other infidels announced by the papal legate at the end of the fifteenth century led to mass crimes against Jews. Many were killed by crusaders in Kraków. At that time, King Jan Olbracht allowed Jews to live in the city of Kazimierz near Kraków. ${ }^{48}$ The chronicle of the Poznanian Bernardines also contains information on a great peasant uprising in Lithuania in 1744, known otherwise from the Pinkas of the Jewish community in Mścisław. ${ }^{49}$ The leader of the uprising, Woszczyłło, is written to have turned the Catholic commoners against the Jews, who were abusing their positions as magnate lease administrators and harassing the peasants with tributes. According to the chronicle, five thousand peasants killed two thousand Jews by drowning

${ }^{44}$ Ibid., 81, 82, 92, 93, 109.

45 Ibid., 130-131, 185.

${ }^{46}$ Ibid., 135, 136, 138, 140, 141, 143, 158, 160, 167, 183.

47 Ibid., 151.

48 Jan of Komorów, “Krótka Kronika Zakonu Braci Mniejszych. Cz. 2,” 558-559.

${ }^{49}$ Israel Halperin, "Bunty woszczyłłowskie," Biuletyn Żydowskiego Instytutu Historycznego 26 (1958), 28-41. 
and other methods. The pogroms were put to an end by soldiers of the Commonwealth, who "smashed and punished the peasants." 50

Furthermore, the chronicle of the Poznanian Jesuits contains an entry from 1572 about an anonymous fellow believer, who during a sermon baselessly accused the Jews of "disgraceful crimes". This was met with a harsh reaction from the local councilmen, as it was not his first "slanderous lie." The monastery authorities thus warned him "that he shall not dare to utter such things again unless he is certain, and proceed to thoroughly investigate the matter together with those whom the utterance concerns." ${ }^{51}$ The chronicle of the Poznanian Bernardines describes much more serious criminal events, which took place in the estate of Smoleńsk voivode Piotr Sapieha (1701-1771). In September 1763, three Jewish men and one Jewish woman cruelly murdered a sixteen-year-old girl in his garden. They were all caught and tried. The woman and two of the men were baptized and sentenced to death. After they were killed, they were "buried with reverence." The third Jew died as such in prison, most likely as a result of torture. He was then "dragged by horses through the streets and past the synagogue as a mockery, [after which] he was left outside the city at the scene of the crime without a burial." ${ }^{52}$

Information about fights between Jews and Christians can only be found in the chronicle of the Poznanian Jesuits from the period of 1570-1653. Six such events took place during this period. Although it was the Jesuits who were often accused of turning the students of their schools against infidels, they often did not take these accusations seriously. For example, on 3 August 1575, during the trial of a pupil and son of a Poznań resident (who beat a Jew and was imprisoned at the order of the mayor of Poznan, Stanisław Brzeźnicki, and later brought to court in the town hall) the Jesuit rector asked the City Council if such trivial misdemeanors could be dealt with at the college. The rector added that "If there is by any chance a more serious accident, for which a school punishment is insufficient, then it shall be adjudicated by the starosta for nobles, and the City Council for commoners. ${ }^{" 53} \mathrm{He}$ also said that such proceedings from the city authorities "take away students' freedom and privileges, and provoke violent and unjustified attacks on the bishop's manor," and that

\footnotetext{
50 "Zaginiony rękopis kroniki domowej," 364.

${ }^{51}$ Kronika jezuitów poznańskich, 19-20.

${ }^{52}$ Kamieński, [“Kronika poznańska”], 284.

${ }^{53}$ Kronika jezuitów poznańskich, 32.
} 
he "did not approve of the mayor's actions." Furthermore, "the mayor, embarrassed by his hastiness, promised to be easier on the students in the future. ${ }^{~}{ }^{54}$ Nevertheless, the words of voivode Stanisław Gorka quoted in this chronicle can be taken as proof that fights with the Jews were initiated by pupils of the Jesuits. At the opening of the inauguration of his office in Poznań on 20 June 1576, he asked the Jesuits "to restrain their youth from attacking the Jews, the care of whom has been entrusted to him." 55

However, this request was not always honored, as the pupils of Jesuit schools continued to pick regular fights with Jews (also referred to as "uproars", tumulty), which took place, inter alia, on 24 June 1579,56 24 August 1601,,$^{57} 21$ April 1626, ${ }^{58}$ and $24-25$ May $1628 .{ }^{59}$ But the Jesuits were able to prevent some incidents, such as on 7 August 1618, when the Jews harmed a painter, "who had painted a lurking Jew on the facade of the town hall," ${ }^{60}$ and in retaliation were attacked by the commoners; as well as on 31 July 1639, when Jews were attacked during a procession to the Dominican church. ${ }^{61}$ Yet due to earlier conflicts, the bishops and city authorities constantly accused the Jesuits and their pupils of attacks on Jews. ${ }^{62}$

Other spectacular events recorded in monastery chronicles include thefts of monastic property. Especially bold were those concerning liturgical equipment. Two chronicles-namely, that of the Bernardines and the Discalced Carmelites-recorded such a theft from the church in the village of Zakrzewo in the Płock diocese in $1739 .{ }^{63} \mathrm{~A}$ can with the Blessed Sacrament and other silver objects donated to the Church were stolen by

${ }^{54}$ Ibid.

55 Ibid., 39.

${ }^{56}$ Ibid., 52-53.

${ }^{57}$ Ibid., 140.

58 Ibid., 314.

${ }^{59}$ Ibid., 326.

${ }^{60}$ Ibid., 286.

${ }^{61}$ Ibid., 388.

${ }^{62}$ Ibid., 286, 388.

${ }_{63}$ The chronicles contain two different names for the village where the theft took place. In that of the Discalced Carmelites, it is called Jerzewo, and in that of the Bernardines, Zakrzewo. The former is located in the Łowicz region in the current Łódź voivodeship, and is most likely incorrect. There is also a problem with the second, as there are four villages with this name in the vicinity of Sierpc, where the thief was from. Two are in Płock county (Zakrzewo and Zakrzewo Kościelne), one is in Lipno county, and one is in Włocławek county. Within the Płock diocese, there are many more villages called Zakrzewo. Determination of the exact location of the event requires further research. 
an anonymous Jew from Sierpc. He intended to sell the host inside the can for a few cents to his fellow Jews there. When word of the theft spread, the thief escaped in an unknown direction. The case was brought before the Crown Tribunal in Piotrków, which, in the absence of the perpetrator, ordered the demolition of his home, and erection of a brick column in its place. At the top, there was to be a chalice with the image of the host and the inscription, "I have come up against this place to destroy it" (2 Kings 18:25); and in the middle, the aphorism, "Learn righteousness and do not disrespect the saints," as well as the following text, written in both Latin and Polish:

Here is the site of a terrible crime, cry you must.

Our priceless Lord was sold for a single coin.

For this heinous act, on a decree from the Court of the Crown,

The home that stands here was razed to the ground.

The court could not dismiss a true case on the profanation of hosts.

In memory of the court victory, a column was erected where the home in Sierpc once stood. ${ }^{64}$

The chronicles do not indicate if this order was ever carried out, or who was supposed to pay for it. Such questions could most likely be answered by a study of source materials concerning the history of Sierpc.

Jews are mentioned in other chronicle entries concerning theft, and not always as perpetrators. They also appear as suspects, receivers of stolen goods, victims of theft, and assistants in catching thieves. ${ }^{65}$ There is a peculiar example in the chronicle of the Poznanian Benedictine Sisters, according to which, in 1636, a Jew in Poznan was robbed by the "soul of Bartosz the organist," dead and wandering like that of a monk. After some time, the soul returned the money directly to the Jew's home by dropping it through the chimney, hitting the landlord by accident. ${ }^{66}$

64 "Tu miejsce strasznej zbrodni, tu płakać w przemiany / Bóg nieoszacowany za tynfa przedany. / Z dekretu trybunału o tak straszną winę / Dom z ziemią porównany poniósł tę ruinę. / Tak słuszna, że nie mogła upaść w sądach sprawa / Zwycięskich w obalinach w Sierpcu kolos stawa." "Zaginiony rękopis kroniki domowej," 363; Kronika poznańskich Karmelitów Bosych, 249.

${ }^{65}$ In 1636, 1719, 1766, and 1768-1769. "Kronika benedyktynek poznańskich," in Kroniki Benedyktynek poznańskich, 88-89; "Młodsza kronika zakonna benedyktynek poznańskich," in Kroniki Benedyktynek poznańskich, 273; Kroniczka rezydencji Karmelitów, 67, 132, 133, 159, 165.

66 "Kronika benedyktynek poznańskich," 88-89. 
Monastery chronicles also contain references to Jews as mere spectators or witnesses to events, ${ }^{67}$ as well as information regarding the locations of buildings (including synagogues), streets, and Jewish cemeteries. ${ }^{68}$

What is interesting is that the chronicles in question usually refer to Jews as a collective group. They are rarely listed by name, with the exception of neophytes, whose names are given only after baptism. Abraham Ezofowicz was mentioned in two chronicles, but only as a treasurer, and not as a Jew. ${ }^{69}$ The chronicles hardly ever contain the phrase "honest Jew;" though one describes how, in 1773, Jews in Kostrzyn informed the authorities of a poor woman who wanted to sell them her child for two złotys. $^{70}$ Records of the Jesuits also show that they taught basic Hebrew at the college in Poznań from 1598 to $1614 .^{71}$

The chronicles describe Jews as unfaithful or malicious, and put them in the same category as heretics and pagans. ${ }^{72}$ The Carmelites wrote that only the Swedish King Carl Gustav, when visiting Prussia in 1655, could jokingly mistake one of their monks, disguised as a highlander for a secret mission, with a Jew. ${ }^{73}$ Despite the fact that Jews, like other inhabitants of the Commonwealth, were subject to plundering, confiscation, tributes, and displacement by Russian or Prussian armies, a few chronicles referring to the second half of the eighteenth century accuse them of cooperating with and willingly submitting to invaders. For example, a Bernardine chronicler from Poznań wrote in 1763 that Jews in the city "publicly displayed an image of the Prussian king in the synagogue with the following inscription: 'May Frederick II the pious, the happy, the father of the fatherland, the defender of peace, live and thrive,' and they sang, 'The war will cease when Poland is divided." ${ }^{74}$ Moreover, according to a Carmelite chronicler from Poznań, Jews from Lesser Poland were craftily planning to transport a large amount of out-of-circulation silver to Breslau in Prussia (now Wrocław in Poland) in November of 1767 . The silver was intercepted "by guardians of

${ }^{67}$ Kamieński, ["Kronika poznańska”], 200, 201, 213.

${ }^{68}$ For example, 1) buildings: Kroniczka rezydencji Karmelitów, passim; 2) streets: ibid.; Kronika poznańskich Karmelitów Bosych, 112; "Zaginiony rękopis kroniki domowej," 356; 3) cemeteries: Kamieński, ["Kronika poznańska”], 199; Kroniczka rezydencji Karmelitów, 74.

${ }^{69}$ Jan of Komorów, "Krótka Kronika Zakonu Braci Mniejszych. Cz. 2,” 581; "Z kroniki Jana Komorowskiego," in Kroniki Bernardynów poznańskich, 37.

70 “Zaginiony rękopis kroniki domowej," 389; Targosz, Piórem zakonnicy, 249.

${ }^{71}$ Kronika jezuitów poznańskich, 127, 237.

72 Dzieje kapitularne zakonnic świętej matki Brygitty, 62.

73 Targosz, Piórem zakonnicy, 231-232.

74 “Zaginiony rękopis kroniki domowej," 368, 369, 385. 
the Crown Treasury" in Zbąszyń, and its value was estimated at 115,000 Polish florins. It was then transported to Poznań, from where it was to be sent to the Royal Treasury in Warsaw. ${ }^{75}$

\section{Summary}

How are Jews portrayed in the analyzed sources? It seems that the authors of the monastery chronicles were primarily interested in Jews as converts to Christianity, although it did occur that they were accused of attempting to convert Christians to Judaism. Emphasis was frequently put on the conversion of Jews to Christianity in response to alleged profanation of hosts and ritual murders highly publicized by the Church. The majority of such events seem to have taken place in Poznań. Somewhat less prominent in monastery chronicles are references to standard contacts between monastery authorities and Jewish contractors, merchants, leaseholders, craftsmen, debtors, and doctors. Descriptions of events important for a given monastery or city only mention Jews "in passing"-either as being among those affected or as the perpetrators of various cataclysms, crimes, beatings, thefts, and tributes. Sometimes, they were even accused of cooperating with foreign armies. The frequency of such references is probably directly proportional to the percentage of Jews living in a given locality.

A more detailed analysis of the source material used for this article requires a review of all available monastery chronicles from the Old Polish period. Only then will we be able to attempt to identify the specific circumstances related to records on Jews and other religious minorities, and formulate far-reaching conclusions and territorial implications.

To sum up, it should be noted that monastery chronicles from the times of the Polish-Lithuanian Commonwealth provide very valuable insight into not only the history of individual orders and the Polish clergy, but of mentality, daily life, and religious and ethnic minorities. Although Judaic subject matter is rather sporadic in such chronicles, it is nevertheless very diverse, and concerns almost all aspects of Jewish life in Poland and abroad. It is also an excellent complement to other sources in the field, including Jewish provenance, and various other institutions and offices of laity. It should be noted, however, that the credibility of the information

${ }^{75}$ Kroniczka rezydencji Karmelitów, 116. 
contained in monastery chronicles is always dependent on the distance in time and space between the chronicler and the events being described, which should - if possible—be verified against other source documents from the same time period.

Translated by Jack Ramsey Zagorski

Stefan Gąiorowski Jagiellonian University in Kraków Polish Academy of Sciences st.gasiorowski@uj.edu.pl 